\title{
PERSEPSI MASYARAKAT TERHADAP KEBIJAKAN POLITIK DI KOTA PAREPARE
}

Rudi Hardi

Fakultas Ilmu Sosial dan Ilmu Politik Universitas Muhammadiyah Makassar Jl. Sultan Alauddin No. 259 Makassar 90221

Telp. 0411 - 866972 ext. 107 Fax. 0411 - 865588

\section{ABSTRAK}

D alam dunia politik, peranan etika politik tidak dapat diabaikan. Hal ini terkait dengan, moralitas politik berguna untuk menyelidiki apa yang mengkonstitusi baik-buruk, keutamaan, keabsahan hukum, kebenaran suara hati, kewajiban moral politik dan sebagainya. Realitas persoalan yang dihadapi dalam budaya politik adalah adanya gap antara campur tangan Politik dengan indenpendensi birokrat (Administrator) tentang pengelolaan pelayanan pada Masyarakat. Kemudian, terdapat sikap dan perilaku yang "negatif", baik politisi mau pun birokrat dalam melaksanakan fungsi masing-masing.. Tujuan penelitian ini adalah untuk mengidentifikasi etika budaya politik dan tanggapan/sikap masyarakat terhadap perkembangan kondisi dan situasi budaya politik di Kota Parepare.

Metode yang digunakan adalah Survey sampel dengan unit analisis masyarakat pemilih. Responden diambil dengan stratified random sampling dari masyarakat kota Parepare. Instrumen penelitian adalah pedoman wawancara dan kuesioner. Analisa yang digunakan adalah deskriptif pada data kualitatif.

Hasil penunjukkan bahwa secara keseluruhan, baik lapisan bawah, menengah, dan lapisan atas, menilai bahwa etika politisi di kota Parepare relatif buruk, yaitu 191 (63,67\%) dari 300 responden. Dan alasan responden adalah bahwa setelah menjadi politisi, mereka cenderung individual atau memikirkan kepentingan diri, keluarga dan atau partainya yang terlihat dari kebijakan-kebijakan yang mereka lahirkan. Hal itu sangat berbeda dengan waktu kampanye.

Kesimpulan, dalam mewujudkan partisipasi politik di kota Parepare, masyarakat memiliki dua ciri atau bentuk dari partisipasi politik berdasarkan sifat yaitu dimobilisasi dan otonom. Kemudian, untuk menilai bagaimana etika politik di Kota Parepare, ada tiga pola pola sikap dan orientasi individu terhadap politik, yakni: (1). Orientasi Kognitif : pengetahuan, keyakinan (2). Orientasi Afektif : perasaan terkait, keterlibatan, penolakan dan sejenisnya tentang obyek politik, dan (3). Orientasi Evaluasi : penilaian dan opini tentang obyek politik yang biasanya melibatkan nilai-nilai standar terhadap obyek politik dan kejadian-kejadian.

Kata Kunci: Persepsi, Masyarakat, Etika, Kebijakan, Etika Politik

\section{A. PENDAHULUAN}

\section{Latar Belakang}

Perubahan UUD 1945 telah mewujudkan konstitusi Indonesia yang memungkinkan terlaksananya penyelenggaraan negara yang modern dan demokratis. Semangat yang diemban dalam perubahan konstitusi tersebut adalah supremasi konstitusi, keharusan dan pentingnya pembatasan kekuasaan, pengaturan hubungan dan kekuasaan antarcabang kekuasaan negara secara lebih tegas, penguatan sistem checks and balances antar cabang kekuasaan, penguatan perlindungan dan penjaminan hak asasi manusia, dan pengaturan hal-hal mendasar di berbagai bidang kehidupan.

Semangat tersebut di atas dapat terlihat dari adanya penegasan yang mengatur pelaksanaan kedaulatan rakyat; pernyataan bahwa Indonesia adalah negara hukum; kesejajaran kedudukan antarlembaga negara sehingga tidak dikenal lagi adanya lembaga 
tertinggi negara dan tinggi Negara tetapi setiap lembaga negara melaksanakan tugas dan wewenangnya sesuai UUD 1945; pembatasan masa jabatan Presiden dan Wakil Presiden hanya maksimal dua kali masa jabatan; seluruh anggota lembaga perwakilan dipilih dan tidak ada lagi yang diangkat; pemilihan Presiden dan Wakil Presiden secara langsung oleh rakyat; kekuasaan membentuk undang-undang di tangan lembaga legislatif; pembentukan lembaga perwakilan baru Dewan Perwakilan Daerah (DPD) yang memperkuat posisi daerah dalam sistem ketatanegaraan kita; dan pembentukan lembaga pelaksana kekuasaan kehakiman baru Mahkamah Konstitusi (MK).

Selain itu juga dimuat ketentuan mengenai pemilihan umum setiap lima tahun dan diselenggarakan oleh suatu komisi pemilihan umum yang bersifat nasional, tetap, dan mandiri; pengaturan mengenai wilayah negara; ketentuan mengenai hak asasi manusia yang sangat rinci, dan pengaturan hal-hal mendasar berbagai bidang kehidupan seperti ekonomi, pendidikan, pertahanan dan keamanan, ilmu pengetahuan, kesejahteraan sosial, kebudayaan, dan lain-lain.

Perubahan-perubahan budaya politik di atas merupakan elemen penting dalam sebuah sistem politik. Perubahan tersebut juga menjadi wajah baru sistem demokrasi yang diterapkan di Indonesia. Meskipun ada perbedaan pandangan mengenai derajat pentingnya pengaruh budaya dalam proses membangun demokrasi, namun hampir semua ahli politik sependapat bahwa budaya merupakan faktor yang mempengaruhi terkonsolidasinya demokrasi.

Pada sisi lain, dalam dunia politik, peranan etika politik sangat penting. Terkait dengannya, moralitas politik berguna untuk menyelidiki apa yang mengkonstitusi baik-buruk, keutamaan, keabsahan hukum, kebenaran suara hati, kewajiban moral politik dan sebagainya. Apa yang disebut sebagai dasar pertimbangan bukanlah berada pada cakupan jurisprudence atau pedagogy dari moral politik saja, tetapi seharusnya berdasarkan pada etika.

Tatkala kondisi moralitas politik memungkinkan apa yang dianggap benar untuk kasus pada waktu tertentu tetapi menjadi salah pada kasus lain di waktu lain, maka sistem kenegaraan ini sedang mengabaikan kemungkinan bahwa seorang diktator akan muncul kembali untuk menyalahgunakan kekuasaannya, atau mempertahankan kekuasaan berdasarkan moralitas personalnya (dalam arti beyond his term of office). Sebaliknya, semakin banyak kekuasaan yang membebaninya, sementara kekuasaan itu menjadi baju untuk lebih berkuasa, maka ia akan menyalahgunakan sekaligus tetap mempertahankan kekuasaan itu.

Kedua sisi ini, budaya politik dan etika politik menjadi hal penting dalam era otonomi. Karena itu, kajian ini terfokus pada etika politik di kota Parepare. Realitas persoalan yang dihadapi dalam budaya politik adalah adanya gap antara campur tangan Politik dengan indenpendensi birokrat (Administrator) tentang pengelolaan pelayanan pada Masyarakat. Kemudian, terdapat sikap dan perilaku yang "negatif", baik politisi mau pun birokrat dalam melaksanakan fungsi masingmasing. Serta berkembangnya dalam kehidupan masyarakat toleransi dan antipati masyarakat terhadap etika politisi.

Sehingga kegiatan kajian etika budaya politik menjadi suatu kebutuhan realistik untuk diwujudkan dalam membangun sosial politik di Kota Parepare.

Dengan demikian, hal-hal yang menjadi per-tanyaan penting untuk dijawab melalui kajian yang mendalam adalah :

1. Bagaimana realitas budaya politik di Kota Parepare?

2. Bagaimana etika politikyang berkembang di Kota Parepare?

3. Bagaimana masyarakat menyikapi perkembangan etika politik di kota Parepare?

\section{B. TINJAUAN TEORITIS}

Untuk mendukung studi ini digunakan beberapa teori yang relevan serta berkaitan dengan pokok bahasan dalam studi sebagai berikut: 


\section{Sistem Politik}

Dalam perspektif sistem, sistem politik adalah subsistem dari sistem sosial. Perspektif atau pendekatan sistem melihat keseluruhan interaksi yang ada dalam suatu sistem yakni suatu unit yang relatif terpisah dari lingkungannya dan memiliki hubungan yang relatif tetap diantara elemen-elemen pembentuknya. Kehidupan politik dari perspektif sistem bisa dilihat dari berbagai sudut, misalnya dengan menekankan pada kelembagaan yang ada kita bisa melihat pada struktur hubungan antara berbagai lembaga atau institusi pembentuk sistem politik. Hubungan antara berbagai lembaga negara sebagai pusat kekuatan politik misalnya merupakan satu aspek, sedangkan peranan partai politik dan kelompok-kelompok penekan merupakan bagian lain dari suatu sistem politik. Dengan merubah sudut pandang maka sistem politik bisa dilihat sebagai kebudayaan politik, lembaga-lembaga politik, dan perilaku politik.

Model sistem politik yang paling sederhana akan menguraikan masukan (input) ke dalam sistem politik, yang mengubah melalui proses politik menjadi keluaran (output). Dalam model ini masukan biasanya dikaitkan dengan dukungan maupun tuntutan yang harus diolah oleh sistem politik lewat berbagai keputusan dan pelayanan publik yang diberian oleh pemerintahan untuk bisa menghasilkan kesejahteraan bagi rakyat. Dalam perspektif ini, maka efektifitas sistem politik adalah kemampuannya untuk menciptakan kesejahteraan bagi rakyat.

Namun dengan mengingat Machiavelli maka tidak jarang efektifitas sistem politik diukur dari kemampuannya untuk mempertahankan diri dari tekanan untuk berubah. Pandangan ini tidak membedakan antara sistem politik yang demokratis dan sistem politik yang otoriter.

\section{Partisipasi Politik}

Partisipasi politik oleh para sarjana di negara Barat sering hanya dipandang sebagai kegiatan yang dilakukan untuk memberikan input bagi pengambil kebijakan menuruti aturan main yang berlaku. Definisi yang demikian membuat partisipasi politik di negara-negara berkembang sulit dikategorikan sebagai bentuk partisipasi politik. Untuk mengatasi hal tersebut, Huntington mencoba mengatasi dengan mengatakan bahwa partisipasi yang tergolong negatif di mata para sarjana di negara-negara berkembang pada dasarnya termasuk pula bentuk partisipasi politik. Kecenderungan mobilisasi di masyarakat negara-negara berkembang menjadi ciri khas yang melekat karena karakteristiknya yang khas selain tidak bekerjanya sistem politik secara baik untuk memberikan kesempatan kepada masyarakat memberikan input tanpa takut diintimidasi oleh pemerintah.

Apatisme juga menjadi persoalan tersendiri dalam studi mengenai partisipasi politik. Secara harfiah apatisme tidak dapat dikatakan sebagai suatu bentuk partisipasi karena seseorang tidak melakukan tindakan apa pun untuk mempengaruhi kebijakan ataupun memberikan input bagi pengambil kebijakan. Akan tetapi, apabila itu dilakukan dengan sadar sebagai bentuk protes atau ketidaksukaan terhadap apa yang dilakukan oleh pengambil kebijaksanaan, tindakan apatisme dapat pula dikategorikan sebagai satu bentuk input dan dengan demikian dapat dinilai sebagai suatu tindakan partisipasi.

\section{Pembangunan Politik}

Sejak awal kehidupan manusia-berjuta tahun yang lampau-manusia dihadapkan pada berbagai macam perubahan aktual alam semesta di mana dia hidup. Lambat laun, respon atas fenomena alam ini bertransformasi menjadi sikap mengatasi perbedaanperbedaan yang terjadi di antara umat manusia, respon atas interaksi sosial ini kemudian mengubah cara dan kebiasaan hidup mereka. Hal ini terus berkembang secara evolutif sekaligus revolutif, hingga sampai pada diketemukannya model pelembagaan pengaturan masyarakat dalam bingkai negara, beserta ilmu yang menyertainya, politik.

Kondisi politik pasca Reformasi menjadikan masyarakat dihidangkan dengan dengan sistem baru yang menuntut 
masyarakat untuk lebih terlibat secara proaktif didalamnya. Dalam penerapannya tidaklah semudah membalikkan telapak tangan, sehingga dalam mewujudkannya perlu ada langkah-langkah yang harus dilakukan secara bertahap. Peningkatan kesadaran politik masyarakat serta penanaman nilai tidak boleh diabaikan, hal inilah yang kita inginkan dalam proses pembangunan politik.

Lucian W. Pye menyimpulkan tiga tema besar yang berhubungan dengan makna pembangunan politik. Pertama, terjadinya pertambahan persamaan (equality) antara individu dalam kaitannya dengan sistem politik, kedua pertambahan kemampuan (capacity) dalam hubungannya dengan lingkungannya, dan yang ketiga pertambahan pembedaan (differentation and spesia-litation) lembaga dan strukur didalam sistem politik tersebut. Pembangunan politik dalam hal ini erat kaitannya dengan budaya politik, strukturstruktur politik yang berwenang serta proses politik.

\section{Budaya Politik}

Kebudayaan politik Indonesia pada dasarnya bersumber pada pola sikap dan tingkah laku politik yang majemuk. Namun dari sinilah masalah-masalah biasanya bersumber. Mengapa? Dikarenakan oleh karena golongan elite yang mempunyai rasa idealisme yang tinggi. Akan tetapi kadar idealisme yang tinggi itu sering tidak dilandasi oleh pengetahuan yang mantap tentang realita hidup masyarakat. Sedangkan masyarakat yang hidup di dalam realita ini terbentur oleh tembok kenyataan hidup yang berbeda dengan idealisme yang diterapkan oleh golongan elit tersebut.

Corak pertama terdapat pada golongan elite strategis, yakni kecenderungan untuk memaksakan subyektifisme mereka agar menjadi obyektifisme, sikap seperti ini biasanya melahirkan sikap mental yang otoriter/totaliter. Corak kedua terdapat pada anggota masyarakat biasa, corak ini bersifat emosional-primordial. Kedua cirak ini tersintesa sehingga menciptakan suasana politik yang otoriter/totaliter.

Sejauh ini kita sudah mengetahui adanya perbedaan atau kesenjangan antara corak- corak sikap dan tingkah laku politik yang tampak berlaku dalam masyarakat dengan corak sikap dan tingkah laku politik yang dikehendaki oleh Pancasila dan UndangUndang Dasar 1945. Kita tahu bahwa manusia Indonesia sekarang ini masih belum mencerminkan nilai-nilai Pancasila itu dalam sikap dan tingkah lakunya sehari-hari. Kenyataan tersebutlah yang hendak kita rubah dengan nilai-nilai idealisme pancasila, untuk mencapai manusia yang paling tidak mendekati kesempurnaan dalam konteks Pancasila.

Dua faktor yang memungkinkan keberhasilan proses pembudayaan nilai-nilai dalam diri seseorang yaitu sampai nilai-nilai itu berhasil tertanam di dalam dirinya dengan baik. Kedua faktor itu adalah; 1. Emosional psikologis, faktor yang berasal dari hatinya. 2 . Rasio, faktor yang berasal dari otaknya

Klasifikasi budaya politik oleh Gabriel A. Almond dan G. Bingham Powell, terdiri atas budaya politik parokial, budaya politik subjek/kaula, dan budaya politik partisipan. Sedangkan budaya politik menurut Austin Ranney dibedakan atas orientasi kognitif dan preferensi politik.

Ada beberapa unsur yang berpengaruh atau melibatkan diri dalam proses pembentukan budaya politik nasional, yaitu sebagai berikut.

1. Unsur sub-budaya politik yang berbentuk budaya politik asal.

2. Aneka rupa sub-budaya politik yang berasal dari luar lingkungan tempat budaya politik asal itu berada.

3. Budaya politik nasional itu sendiri.

Tahapan perkembangan budaya politik nasional menurut Sjamsuddin, antara lain sebagai berikut (Rahman, 1998: 58).

1. Budaya politik nasional yang tengah berada dalam proses pembentukannya.

2. Budaya politik nasional yang sedang mengalami proses pematangan. Dalam tahapan ini, pada dasarnya budaya politik nasional sudah ada, tetapi masih belum matang.

3. Budaya politik nasional yang sudah mapan, yaitu budaya politik yang telah diakui keberadaannya secara nasional. 
4. Ada dua sudut pandang untuk melihat budaya politik yang dikaitkan dengan struktur sosial, yaitu secara vertikal maupun horizontal.

Terakhir ada tiga kelompok yang mempunyai pengaruh yang sangat kuat terhadap sistem politik Indonesia, yaitu kelompok agama, kelompok suku bangsa, dan kelompok ras.

\section{METODE PENELITIAN}

Kegiatan kajian etika budaya politik dilakukan dengan menggunakan metode survey sampel. Populasinya adalah pelaku politik di Kota Parepare. Pada pengkajian ini, yang akan diteliti, ditelaah dan diterangkan adalah etika budaya politik di kota Parepare. Karena itu, metode yang digunakan adalah metode kualitatif, metode kuantitatif, dan ataupun gabungan antara keduanya, terutama nampak pada analisanya. Metode kuantitatif menggunakan angka-angka (Tabulasi, statistik inferensial), menghubungkan antara angka yang satu dengan angka yang lainnya kemudian menarik makna. Sedang metode kualitatif menggunakan makna: menghubungkan antara makna yang satu dengan makna yang lainnya kemudian menarik yang lebih luas atau lebih dalam, atau yang lebih tinggi tingkatannya.

Pada dasarnya ada beberapa jenis studi dan teknik pengumpulan data yang diterapkan untuk kajian ini, sebagai berikut:

Stakeholders studies, dimaksudkan untuk mendapatkan data dan informasi mengenai pandangan/penilaian para pemangku kepentingan atau stakeholders (Pemerintah, DPRD, Partai Politik, kalangan Lembaga non pemerintah, pakar/akademisi dan tokohtokoh masyarakat lainnya tentang berbagai regulasi, kebijakan maupun implementasi dari kebijakan yang berhubungan dengan berbagai aspek etika budaya politik. Ada dua teknik pengumpulan data yang diterapkan untuk stakeholder studies, yaitu indepth interview dan FGD.

Policy Impact Studies (PIS). Policy impact studies atau studi dampak kebijakan dimaksudkan untuk melihat dampak kebijakan berupa Peraturan Daerah dan Surat Keputusan Walikota dalam mengatur usaha kecil Kota Parepare.

Studi literatur. Sebelum penelitian lapangan dilakukan, tim peneliti terlebih dahulu telah melakukan kajian terhadap laporan-laporan studi mengenai etika budaya politik. Beberapa hal yang ditelaah antara lain adalah kacamata analisis/cara pandang dan indikator-indikator yang digunakan dalam rangka melakukan kajian/studi. Di samping itu ditelaah pula hasil-hasil utama (termasuk rekomendasi-rekomendasi) yang diperoleh dari studi. Hasil telaahan ini kemudian dituliskan dalam bentuk overview singkat. Dari hasil overview tersebut peneliti ahli kemudian akan menulis "kajian kepustakaan/literatur review" dengan memasukkan telahaan teori dan konsep mengenai etika budaya politik.

Kajian historis mengenai etika budaya politik. Kegiatan ini dilakukan dengan metode analisis dokumen dan in-depth interview kepada pihak-pihak yang dipandang memiliki pengetahuan mengenai topik kajian yang dilakukan yang kemudian dianalisis dan disusun dalam bentuk position paper.

Teknik Pengumpulan Data, yaitu :

1. Data yang bersifat keterangan dikumpulkan melalui teknik wawancara dengan menggunakan pedoman wawancara (interview guide),

2. Data yang bersifat distribusi/frekuensi dikumpulkan melalui teknik perhitungan atau pencacahan dengan menggunakan kuesioner atau skedul.

3. Data yang bersifat nilai-nilai, norma-norma, kepercayaan (adat dan agama), tingkah laku yang laten (cover behaviuor), dan sejenisnya dikumpulkan melalui teknik pengamatan terlibat secara terbatas dan wawancara dilakukan secara face to face dengan menggunakan catatan lapang (field notes).

\section{HASIL DAN PEMBAHASAN}

\section{Karasteristik Masyarakat Kota Parepare}

Berdasarkan hasil kajian, maka karateristik masyarakat kota Parepare memiliki ciri-ciri sebagai berikut: 
a. Pengaruh alam terhadap masyarakat kota kecil

b. Mata pencahariannya sangat beragam sesuai dengan keahlian dan ketrampilannya.

c. Corak kehidupan sosialnya bersifat gessel schaft (patembayan), lebih individual dan kompetitif.

d. Keadaan penduduk dari status sosialnya sangat heterogen

e. Stratifikasi dan diferensiasi sosial sangat mencolok. Dasar stratifikasi adalah pendidikan, kekuasaan, kekayaan, prestasi, dan lain-lain.

f. Interaksi sosial kurang akrab dan kurang peduli terhadap lingkungannya. Dasar hubungannya adalah kepentingan.

g. Keterikatan terhadap tradisi sangat kecil

h. Masyarakat umumnya berpendidikan lebih tinggi, rasional, menghargai waktu, kerja keras, dan kebebasan.

i. Jumlah warga lebih banyak, padat, dan heterogen.

j. Pembagian dan spesialisasi kerja lebih banyak dan nyata.

k. Kehidupan sosial ekonomi, politik dan budaya amat dinamis, sehingga perkembangannya sangat cepat.

l. Masyarakatnya terbuka, demokratis, kritis, dan mudah menerima unsurunsur pembaharuan.

m. Pranata sosialnya bersifat formal sesuai dengan undang-undang dan peraturan yang berlaku.

n. Memiliki sarana-prasarana dan fasilitas kehidupan yang sangat banyak.

\section{Partisipasi Politik Masyarakat Kota Parepare}

Berdasarkan pada bentuk-bentuk Partisipasi Politik menurut Almond (table 1), maka partisipasi politik masyarakat di Kota Parepare, sebagai berikut:

Tabel 1:

Bentuk-bentuk partisipasi politik menurut Almond (1984:107).

\begin{tabular}{|c|c|}
\hline KONVENSIONAL & NON KONVENSIONAL \\
\hline $\begin{array}{l}\text { 1. Pemberian suara (voting) } \\
\text { 2. Diskusi politik } \\
\text { 3. Keglatan kampanye } \\
\text { 4. Membentuk dan bergabung } \\
\text { dalam kelompok kepentingan } \\
\text { 5. Komunikasi individual dengan } \\
\text { pejabat politik/administratif }\end{array}$ & $\begin{array}{l}\text { 6. Pengajuan petisi } \\
\text { 7. Berdemonstrasi } \\
\text { 8. Konfrontasi } \\
\text { 9. Mogok } \\
\text { 10. Tindak kekerasan poitik terhadap harta benda: } \\
\text { perusakan, pemboman, pembakaran. } \\
\text { 11. Tndak kekerasan politik terhadap manusia: } \\
\text { penculkan, pembunuhan, perang gerilya/revolusi. }\end{array}$ \\
\hline
\end{tabular}

Tabel 2:

Bentuk Partisipasi Politik Responden di Kota Parepare

\begin{tabular}{|c|c|c|c|c|c|c|}
\hline \multirow{3}{*}{$\begin{array}{c}\text { BENTUK PARTISIPASI } \\
\text { POLITIK } \\
\text { (KONVENSIONAL) } \\
\text { mberian suara }\end{array}$} & \multicolumn{6}{|c|}{ PENDAPAT RESPONDEN } \\
\hline & \multicolumn{2}{|c|}{ Sangat Aktif } & \multicolumn{2}{|c|}{ Aktif } & \multicolumn{2}{|c|}{ Tidak aktif } \\
\hline & 263 & $(88 \%)$ & 28 & $(9 \%)$ & 9 & $(3 \%)$ \\
\hline Diskusi politik & 74 & $(25 \%)$ & 31 & $(10 \%)$ & 195 & (65\%) \\
\hline Kegiatan kam & 98 & (33\%) & 154 & $(51 \%)$ & 48 & $(16 \%$ \\
\hline $\begin{array}{l}\text { Membentuk dan bergabung } \\
\text { dalam kelombok keoenting }\end{array}$ & 37 & $(12 \%)$ & 21 & $(7 \%)$ & 242 & $(81)$ \\
\hline $\begin{array}{l}\text { Komunikasi individual dengan } \\
\text { pejabat politik/administratif }\end{array}$ & 51 & $(17 \%)$ & 102 & $(34 \%)$ & 147 & $(49 \%)$ \\
\hline
\end{tabular}

Sumber: Hasil Olahan Kuesioner

Dari table 2, nampak bahwa partisipasi politik dari sisi pemberian suara pada setiap pemilihan umum, baik pemilihan legislatif (DPR/DPD/DPRD) maupun pemilihan presiden (walikota). Ternyata dari 300 responden, 263 (88\%) responden menjawab sangat aktif dan hanya $9(3 \%)$ responden yang menjawab tidak aktif.

Kemudian, partisipasi politik dari bentuk "diskusi politik", ternyata responden menjawab tidak aktif sebanyak 195 (65\%), 75 (25\%) menjawab sangat aktif, dan hanya 31 (10\%) menjawab kadang-kadang aktif. Dan setelah dikonfirmasi, alasan mereka antara lain; sibuk bekerja, tidak dilibatkan dan menghindari perbedaan pendapat dengan orang lain. Sedangkan alasan responden menjawab sangat aktif adalah karena teman atau tetangga mereka yang pengurus partai atau simpatisan melibat dalam pembicaraan politik.

Selanjutnya pendapat responden tentang kegiatan kampanye, mereka cenderung aktif, dan hanya 48 (16\%) yang tidak aktif. Alasan mereka adalah menginginkan baju dan atau bahkan uang dari tim sukses. Berbeda dengan partisipasi politik berbentuk bergabung dengan kelompok kepentingan, terdapat 242 (81\%) responden tidak bergabung secara resmi dalam dalam suatu organisasi yang berkaitan dengan politik. Namun demikian, responden menginginkan adanya komunikasi dengan pejabat politik 102 (34\%) dan 51 (17\%). Dan selebihnya 149 (49\%) mangatakan malu-malu "tidak aktif" berkomunikasi dengan para pejabat politik.

Dengan demikian, partisipasi politik masyarakat di Kota Parepare sangat beragam, dan sangat ditentukan oleh tingkat pendidikan dan jenis pekerjaan yang digeluti. Makin tinggi 
tingkat pendidikan, masyarakat juga cenderung terlibat dalam partisipasi politik, demikian sebaliknya, makin rendah pendidikan makin kecil tingkat partisipasi mereka dalam politik.

\section{Etika Politik Masyarakat}

Orientasi kognitif, yang merupakan pengetahuan masyarakat tentang sistem politik, peran, dan segala kewajibannya. Termasuk di dalamnya adalah pengetahuan mengenai kebijakan-kebijakan yang dibuat oleh pemerintah.

Orientasi afektif, merupakan perasaan masya-rakat terhadap sistem politik dan perannya, serta para pelaksana dan penampilannya. Perasaan masyarakat tersebut bisa saja merupakan perasaan untuk menolak atau menerima sistem politik atau kebijakan yang dibuat.

Orientasi evaluatif, merupakan keputusan dan pendapat masyarakat tentang objek-objek politik yang secara tipikal melibatkan nilai moral yang ada dalam masyarakat dengan kriteria informasi dan perasaan yang mereka miliki.

Secara keseluruhan, tanggapan responden tentang perilaku politisi di kota Parepare dapat dilihat pada table berikut (Tabel 3):

Tabel 3:

Tanggapan Responden tentang perilaku politisi

\begin{tabular}{|c|c|c|c|c|}
\hline \multirow{2}{*}{$\begin{array}{l}\text { PELAPISAN } \\
\text { RESPONDEN }\end{array}$} & \multicolumn{3}{|c|}{ TANGGAPAN RESPONDEN } & \multirow{2}{*}{$\begin{array}{c}\text { JUMLAH } \\
\text { RESPONDEN }\end{array}$} \\
\hline & $\begin{array}{c}\text { SANGAT } \\
\text { BAIK }\end{array}$ & BAIK & BURUK & \\
\hline Bawah & 21 & 37 & 102 & 160 \\
\hline Menenqah & 13 & 23 & 64 & 100 \\
\hline Atas & 6 & 9 & 25 & 40 \\
\hline Total Responden & $\overline{40}$ & $\overline{69}$ & $\overline{191}$ & 300 \\
\hline Persentase & 13.33 & 23.00 & 63.67 & 100.00 \\
\hline
\end{tabular}

Sumber: Hasil Olahan Kuesioner

Dari tabel 3, nampak bahwa secara keseluruhan, baik lapisan bawah, menengah, dan atas menilai bahwa etika politisi di kota Parepare relatif buruk, yaitu 191 (63,67\%). Dan alasan responden adalah bahwa setelah menjadi politisi, mereka cenderung individual atau memikirkan kepentingan diri keluarga dan atau partainya yang terlihat dari kebijakan-kebijakan yang mereka lahirkan. Hal itu sangat berbeda dengan waktu kampanye.

\section{E. KESIMPULAN}

1. Di kota Parepare, dalam mewujudkan partisipasi politik, masyarakat memiliki dua ciri atau bentuk dari partisipasi politik berdasarkan sifat yaitu yang dimobilisasi dan otonom. Dimobilisasi adalah banyak diantara orang-orang yang memberikan suara, dan kampanye yang kelihatannya sebagai partisipasi politik tidaklah bertindak dengan niat pribadi. Sedangkan partisipasi politik otonom mengikuti dengan seksama, menganalisa baik buruknya dan pilihan atau kebijaksanaan yang diambil.

2. Etika politik termasuk lingkup etika sosial yang berkaitan dengan bidang kehidupan politik, politik juga memiliki makna bermacam-macam kegiatan dalam sistem politik dan menyangkut proses penentuaan tujuan dari sebuah sitem yang diikuti oleh pelaksananya, yang menyangkut kepentingan masyarakat dan bukan tujuan pribadi. Untuk menilai bagaimana etika politik di Kota Parepare, ada tiga pola pola sikap dan orientasi individu terhadap politik diantara anggota sistem politik. Orientasi individu itu memiliki sejumlah komponen yakni: (1). Orientasi Kognitif: pengetahuan, keyakinan

(2). Orientasi Afektif : perasaan terkait, keterlibatan, penolakan dan sejenisnya tentang obyek politik, dan (3). Orientasi Evaluasi : penilaian dan opini tentang obyek politik yang biasanya melibatkan nilai-nilai standar terhadap obyek politik dan kejadian-kejadian. Dari hasil analisa, nampak bahwa etika politisi di Kota Parepare relatif buruk.

\section{Karena itu, disarankan:}

1. Agar fungsi politik di kota Parepare berjalan dengan baik, semestinya, politik adalah mekanisme yang digunakan untuk mengatur lalu-lintas distribusi kekuasaan. Subyek sekaligus obyek dalam siklus politik modern adalah rakyat, sementara para elit pejabat berposisi sebagai pelayan mereka. 
Politik harus diabdikan untuk menggapai tujuan daerah, yakni untuk memakmurkan, menyejahterakan dan membahagiakan setiap waga. Struktur kelembagaan daerah, dengan demikian, berfungsi sebagai problem solver bagi berbagai bentuk persoalan yang muncul di masyarakat.

2. Sebaiknya, kekuasaan haruslah impersonal. Artinya, struktur kelembagaan daerah tidak dijalankan atas dasar pola relasi kekerabatan yang bisa menimbulkan bias dan penyelewengan kekuasaan. Loyalitas bawahan dalam sistem semacam ini tidak ditujukan kepada orang-perorang yang berkuasa, tetapi kepada sistem dan struktur kelembagaan daerah. Para elit pejabat hanya menjalankan tugas dan fungsinya dalam rangka merealisasikan terbentuknya daerah berbasis pada kemaslahatan bersama.

\section{DAFTAR PUSTAKA}

Amal, Ickhlasul. 1998. Teori-Teori Mutakhir Partai. Tiara Wacana. Yogyakarta

Apter, E. David. 1998. Pengantar Analisa Politik. PT. Gramedia Pustaka utama. Jakarta

BPS Kota Parepare, 2007/2008. Kota Parepare Dalam Angka, Kota Parepare

BPS Kota Parepare, 2009. Indikator Ekonomi Kota Parepare, Kota Parepare

BPS Kota Parepare, 2010. Kota Parepare Dalam Angka, Kota Parepare

Budiardjo, Miriam. 1980. Partisipasi dan Partai Politik. PT. Gramedia Pustaka Utama. Jakarta

Dahl, A. Robert. 2001. Perihal Demokrasi. Yayasan Obor Indonesia. Jakarta

Davey, K.J., 1988, Pembiayaan Pemerintahan Daerah: Praktek dan Relevansi bagi
Dunia Ketiga, Jakarta: Universitas Indonesia.

Erani Yustika, Ahmad Kontestasi Politik dan UMKM, http://ww.ahmadheryawan.com

Faisal, Sanafiah. 1989. Sistem Politik Indonesia. CV. Rajawali. Jakarta

Fakih, mansour, 1996. Masyarakat sipil menuju transformasi sosial, yogyakarta : pustaka pelajar.

Gabriel A. Almond dan Sydney Verba, The Civic Culture: Political Attitudes and Democracy in Five Nations (Princeton: Princeton University Press, 1963)

Gabriel Almond, "Comparative Political Sistem," Journal of Politics, 18 (1956).

Gabriel Ben-Dor, "Political Culture Approach to Middle East Politics," International Journal of Middle East Studies, Vol. 8, No. 1 (Jan., 1977).

Hikam, A.S. 1999. Politik Kewarganegaraan. Erlangga. Jakarta

Kartasasmita, Ginanjar, 1996, Pembangunan untuk Rakyat: Memadukan Pertumbuhan dan Pemerataan, Cetakan I, Pustaka Cidesindo, Jakarta.

Mahendra, Oka, A.A. dan Soekady. 2004. Sistem Multi Partai Prospek Politik Pasca 2004. Yayasan Pancur Siwah. Jakarta

Mannheim, K. 1991. Ideologi and Utopia: Menyingkap Kaitan Pikiran dan Politik. Penerbit Kanisius. Jakarta.

Margiono, Ari. Membangun Partai Politikyang Demokrati, www.wordpress.ariblog.com

Mas'oed, Mochtar. 1998. Perbandingan Sistem Politik. Gadjah Mada University Press. Yogyakarta

Maswood, Javed, 2000, International Political 
Economy and Globalization, London: $8^{\text {th }}$ Edition, Prentice-Hall World Scientific Publishing Co.

Muhaimin, Y.A. 1990. Bisnis dan Politik:

Rubin \& rubin, 1986, organization theory : structure, design and applications, new Kebijaksanaan Ekonomi Indonesia 1950-1980. LP3ES. Jakarta.

Obsborne, David and Ted Gaebler, 1992, Reinventing Government: How The Enterpreneurial Spirit is Transforming the Public Sector, Mass: Addison-Wesley Publishing.

Patton, Carl V. \& Sawicki, David S., 1986, Basic Methods of Policy Analysis and Planning, New Jersey: Prentice-Hall Englewood Cliffs.

Pembangunan Jangka Menengah Daerah (RPJMD) Kota Parepare Tahun 20082013), Parepare: Bappeda Parepare.

Permadani, Wahyu, popularitas dan suara terbanyak: pilihan terbaik dari partai politik. www.addpress2007.com jersey : prentice hall.

Sanit, Arbi. 1995. Sistem Politik Indonesia. PT. Raja Grafindo Persada. Jakarta

Santoso, Topo dan Supriyanto, Didik. 2004. Mengawasi Pemilu Mengawal Demokrasi. PT. Raja Grafindo Persada. Jakarta

Sepandji, Kosasih Taruna, 2000, Manajemen Pemerintahan Daerah: Era Reformasi Menuju Pembangunan Otonomi Daerah, Bandung: Penerbit Universal.

Stewart, M. Aileen, 1994, Empowering People, Singapore: Pitman Publishing.

Wicipto Setiad, Peran partai politik Dalam penyelenggaraan pemilu Yang aspiratif dan demokratis, www.legalitas.org

Robbins, S.P. , 1998, Organizational Behavior; Yusnita H, SH, Sistem Pemilu Ideal, Adakah. Concepts, Controversies, Applications, www.wordpress.nitablog.com 